LA-UR-96-170

$$
\text { CONF-960647--7 }
$$

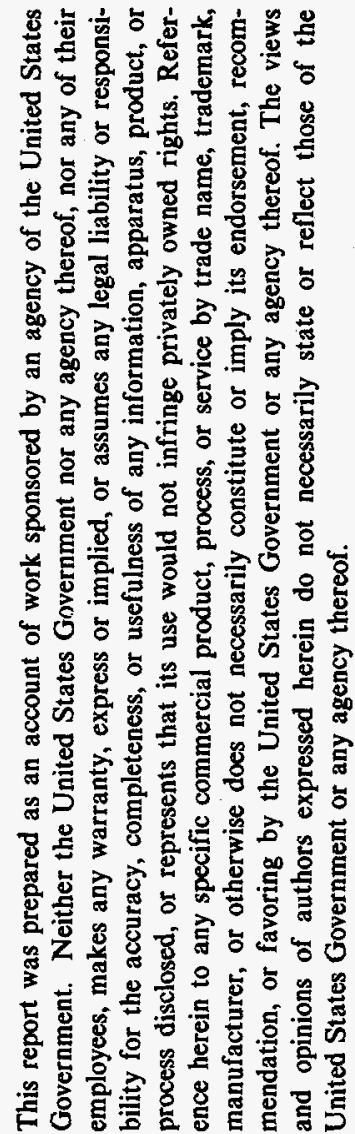

Submitted to

\section{RECEIVED \\ MAR 131996 \\ OSTI}

Michae] D. Garcia, ESA-EA

Ravi Varma, MST-6

A. Sharif lleger, University of New Mexico

International Conference on Probablistic

Safety and Management. PSAM-III,

June 24-28, 1996, Crete, Greece

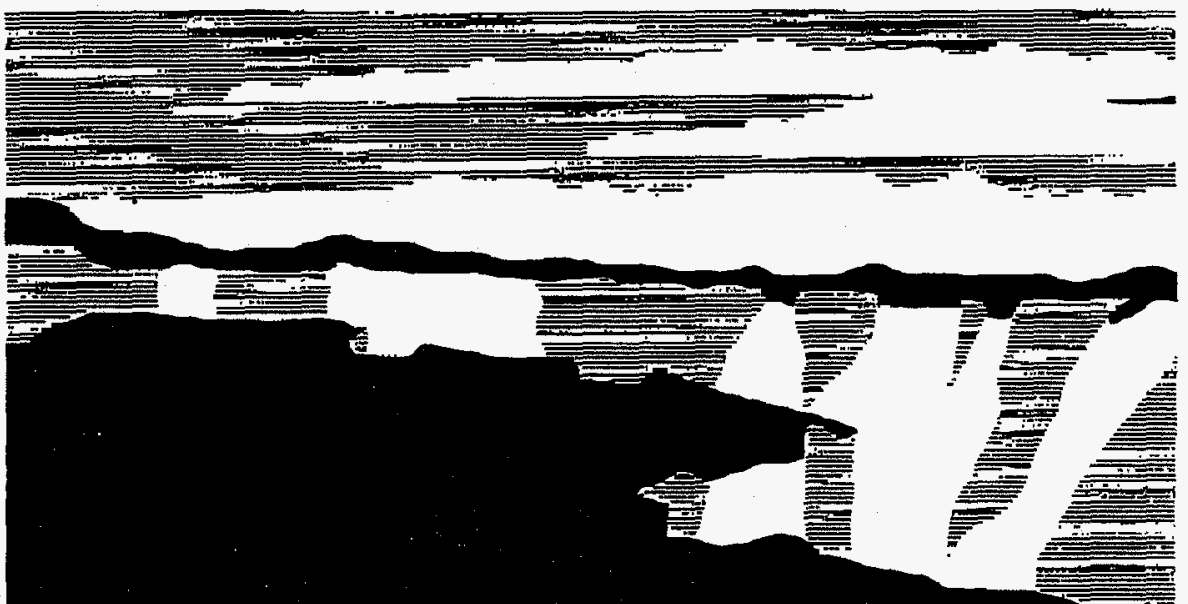

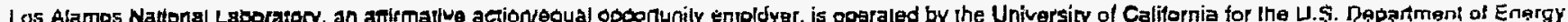
Under contrace W.7AD5-ENG-36. By acceptance of this aticlo. The publisher recognizas that the Ul.5. Government reteing a nonexclusive, royalty-1ree license to

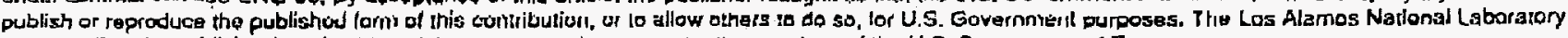
reguests that the publisher identify this aricle as work pertormed under tha auspices of the U,S. Dupariment of Energy. 
NOTICE

Page(s) size did not permit electronic reproduction. Information may be purchased by the general public from the National Technical Information Service, U.S. Department of Commerce, Springfield, VA 22161 (Area Code 703-487-4650). DOE and DOE contractors may purchase information by contacting DOE's Office of Scientific and Technical Information, P.0. Box 62, Oak Ridge, TN 37831, Attn: Information Services (Area Code 423-576-8401). 


\title{
Risk Assessment and Life Prediction of Complex Engineering Systems
}

\author{
Michael D. Garcia and Ravi Vama \\ Los Alamos National Laboratory \\ Los Alamos, New Mexico, U.S.A. \\ A. Sharif Heger \\ The University of Ncw Mexico \\ Department of Chemical and Nuclear Engineering \\ Albuquerque, New Mexico, U.S.A.
}

\begin{abstract}
Many complex engincsring systems will exceed their design lifc expcetancy within the next 10 to 15 years. It is also expected that these systcms must be maintained and operated bcyond their design life. This paper presents a integrated approach for managing the risks associnted with aging effects and prodicting the residual-lifte expectancy these systems. The approach unifics risk assessment, enhanced suryeillance and testing, and robust computational models to assess lic risk, predict age, and develop a life-extension management procedure. It also relies on the state of the art in life-extension and risk assessment methods from the nuclear power industry. Borrowing from the developments in decision analysis, this approach should systematically identify the options available for managing the existing aging systems bcyond their intended design life.
\end{abstract}

\section{Introduction}

This paper establishes specific technical issucs and challenges to assess a complex system in terms of aging effects, life predietion, prediction of railure modes, and providing cost-effective retrofits for aging, complex enginecring systems. In this paper wo define complex in cerms of the basic requirement to iniegrate the risk assessment to a fundamental understanding of the engineering materiais used in the system as thcy detcriorate with age. material syncrgistic ellcels and compatibility issues, and the evaluation of the resuluing change in tolal system reliability. Risk assessment involves identifying and characlerizing most common materials failure llodes of aging, in-service components. For example, corrosion with or without stresses may lead to "Iracture" which constitute major materials failure modes. Radiation damagc in materials (c.g., beryllium, polymers) that results in swelling and decreased tensile strength becomes prone to mechanical fracture. Hydriding of zirconium alloys, for cxample. will degrade the muchanical strength of the element, and this may lead to fracture. 
Life prediction of aging, complex engineering systems will involve the devclopment of robust compulational models that ufilize, a real-lime experimental data base. While a pliysical foundation is essential to achieve gencrality and some measure of confidente in extrapolations, phenomenological constraints is equally crucial for achieving reliability and prediclive valuc in descriptions of macroscopic behaviot, despitc the enormous complexily of underlying physics. There are lessons to be learuted from the research programs $[1,2,3]$ on structural aging and aging of nuclear poiver plants. Much of this work can provide a basis and relevant objectives for developing an integrated plan for life-prediction of aging complex systems. Other aging resurrch programs such as those related to conventional weapons and aircrall must he researched for rclevance.

In this approseh, it is also critical that existing systen surveillance units (if they exisl) provide intorsation and data to support computational model development and predict anticipated failure modcs. For example, we nced to detect and measure the initiation of material degradation which may involve corrosion, the progression stage which may involve microcracks dcveloping during corrusion paricularly in presence of stress, and the ullimate matcrials failure involving mechanical fraclure of the metal/alloy specimen. Certainly measurement lools are needed; some of which may be readily available while others may lave to be developed for the particular applicetion. Additionally, survcillance must be cnhanced to recover a refined set of data and information that direetly supdors the computational models. such as obtaining time-dependent material properties. Where there is no data, we must rely on aceelerated-aging testing to simulate the aging process and extrapolate our models.

Of particular interest is the development of robust computational models to predict failures or sequences of fallures (coupled failures) that have not been observed in existing surveillance or shelve life units, due to synergistic effects or cxisting units that are not old enough to lave iniliated or deteelable failures. Common-mode failures are of panticular interest since they may affect a significant number of common systems.

The four critical competency development areas are:

1) Probabilistic risk assessment (PRA) and reliạbility,

2) Enhanced surveillanes - destructive and nondestructive cvaluation (NDE).

3) Constilutive model development and agcd material properties, and

4) Deterministic computational code modeling.

\section{Critical Capabilities and Associated Technical Issues}

\subsection{Probabilistic Risk Assessment (PLA) and Relinbility}


It is importanl to organize and systemalieally evaluate systcm opsration and sysiam reliability. With PRA system models, failures can be analyzed in terms of how thicy might be initiared, how failures progress, how they might be mitigared, and how human actions might affect their progression. Failure modes for each complex system will difler because each system has different common materials (for cxample, dillerent types of explosives, different special materials, different types of foams, elc- $\rangle_{2}$ different ages, different fabrieation rechuiques, and different assembly procedures. Each complex system also has a unique set of mission environments that it must endure. The same components in the syslem also have differcnt reliabilities due to statistical diferences in the manner in which they are machincd, Iormed, welded, etc, and thcy have different malerial properties. In view of these diferences, it is appropriace to a perform failure modes and eftects analyses (FMEA) that identify the unique set of potential failure modes for cach system.

Generally, failures are defined as an incident or condition and sequente of events that causes the complex system to opcrate unsafely, unreliably, and not costeffeclively. Failure modes that may be considered are rraclure, stress corrosion, pilling, eracking, radiation induced embritlement, radiation damage, hydriding, wear, etc. or a combination of any these failurt modes. Scientific data accunulated from a comprehensive aging research program together with eareful documentation of survcillance experierice make this tool more effective as a practical tool for managing and assuring system safery and reliability, for example, in weighting the relative mirrils of inspection, survcillance, lesting, and maintenance as measures to assure acceptable reliability. This can be accomplished with the general PRA framework.

\subsection{Enhanced Surveillance - Destructive and Nondestructive Evaluation (NDE) Assessment}

Current techniques in support of model development includes metallography, tensile tests, radiography, photography, physical inspection, surface characterization, weight testing, gas lesting, chemistry, and acoustic resonance. In general, however, the emphasis associated with these tests was to ensure conformance to manufacturing specilications. The requirements from the aging and life prediction standpoint is to define an enhanced and robust set of surveillance techniques and sorresponding data lust direclly supports the development of accurate failure and aging computational models.

\subsubsection{Residual-Stress Measurements}

A complementary area for model development is the characterization of residual stresses indueed into as-built components resulting from welding. hightemperature forming, machining, or fabrication. Redistribution of these stresses in as-built configurations will occur duc to cracking, volume expansion due to radjoactive decay daughter-product production, or by othur means. Residual 
stressts can be measured using various methods, including $X$-ray, and strain gauge techniques. The enhineement of old techniques or tice development of new techniques such as using neutron diffraclion rechniques should be explored and developed. Furthermorc, improved fabrication techniques should be explored to relieve stresses (stress-improvement techniques) such as induction healing and mechanical techniqucs, cspccially since potcnibally different fabrication techniques may be implemented in the future.

\subsubsection{Crack Detection Mfeasurements}

In gencral, conventional NDE methods fall to detect incipient damage which can lcad to crack initiation. [ollowed by failure. î is also unlikely thesc methods will determine the uature or location of these cracks or damage within the component or system. Several improved NDE lechniques have becn recently developed for estiulating life consumption. These include strain monitoring tcehniques, micrustructural techniques, hardness-based tcchniques, and ultrasonic testing. Acoustie Emission (AE) are result of stress tvaves in stressed matcrials due to microstructural cvents leading to cracks. An important feature of $A E$ is that it is non-destruerive and non-ininusive and that with suitable sensors, the entirc device or component can be evaluated for hav or cracks in one measurement session. Because of knatvn stress-strain relationships, accurate measurement of residual stress levels in a strueture can be made by measuring strain using highly sensitive resistance strain gaugss. Fiber opric, heterodyne, dual probe intcrferomeler for laser ultrasonic crack detection has been refined to an cxtent such as that haws or erack depth of 100 micron sizes may now be measured.

\subsection{Constitutive Model Development and Aged Material Properties}

The purpose of this area is the devclopment of constitulive material models for aging system materials. The development of this aged-material data base is a basic rcquirement for the development of robust, computational models. This will require the incasurement of eritical material properties as a function of time. The data base will be used to assist in the prediction of long-term deteriaration of critical system components. The bulk macroscopis mechanical properties of interest are typically derived from stress-strain measurements such as the elastic modulus, yield stress, hardness, creep strength, and ultimate stress.

The difficulty associated with development and measurement of the degraded or aged material properties is the fact that it is diffieult, if not impossiblc, to simulate the natural-aging processes that occur within nuclear materials. For example, it is well-known that radiation damage to organic materials may depend not only on the absorbed dose but also on the irradiation time and dose rate. Furthernore tie presence of extemal gas species such as oxygen that may present for diffusion into the organics may strongly influence the amount of permanent damagc to the 
material. Other limitations are tuc fact that naturally-aged materials are not available for the ages of interest. such as ages grearer than 20-years. Addicionally, most of the data on relevant reactor material properties are at high dosc-rates and high temperatures, that typically oceur in nuclear reactors. Vinually all existing information on the aging effects of temperalure and radiation on the properies of organic materials comes from artificial-age conditions.

\subsection{Deterministic Computational Code Modeling}

In general, the computational modcls (c.g. finite element models) must bc developed in eonjunction with the aged-material data bast and constututive models for predicling the residusl-life of complex systems, Furthermore, the models must be verified against accurate experimental dala or extrapolations that are theoretically sound. With aging systerns there is grcaler emphasis on predicling the type of damage or statc-of-suress that may develop in a system as it ages and the initial state of stress as it is delivered for operauion. For example, these computational models will be used to simulate residual stresses present in the components duc to welding or fabrication and then modeling and superimposing the mission environments. This level of damage or inilial slate-of-stress (such as residual stresses, cracking. comosion. etc.) then scrves as initial condicions for subsequent mission cnvironment calculations and the assessment of how the systcm performs. These initial conditions vary depending upon the age of the system and system type.

Aecurate computational modeling of welding must model the weld cooling rate, temperature gradient of the veld pool, turbulence, multiphase flow surface tension now, transient heal Iransfer, weld solidification microstructure, convection of nuclei and grains, and evaporation, of particular interest is the requirement for stress-slrain relationships that are a function of microstructure. Existing modcls also ignore high-temperature strain-rate dependence and creep. Refincment of the existing modeis are required in better understand the welding process and how it affects the residual-life of system components.

In some cases existing flaws or microcracks on a compuncnt or part (e.g., aircraft wing panels) under applicd load or residual stress may suddenly and rapidly propagatc. Crack-growth-rate characteristies for components are important in predicting residual-life of system curnponents. Cracks of less than a critical-size will likely increase in size during mission environmenls. The key issues here are will these cracks be initialed. how they propagate if initiated, what are critical sizes, how fast these eracks grow in size in mission environments, and do the cracks affect system operation. The key concept of the model is the coupling between tlic internal and the external environments involving all the variables that have becil observed to have a significant role in crack growth. 
Comosion is characterized by spatially scparate anodic and calluclic areas and is accompanied by a flow of eleetric current for perceptible distanees through the metal surfaocs. The localized corrosion modes, namely pilling. erevice cortosion, and stress corrosion is more destructive than genteral curtosion (e,g., eorrosion of a steel coupon in ses water, $-.13 \mathrm{~mm}$ per year). Pitung corrosion is usually altended by the breakdown of passivating film on the metal surfaces. Such areas arc adjacent to weld zones in a metallic structust. The use of empirical and deterministic models for calculating crack gruwth rales and for predicting damage functions for pitcing corrosion in stainless steel-403 has been demonstrated to be very successful in their applications to nuclear power reaclor plants, particularly for the heat transport vircuits. For the first time the cxtent of surtace damage by localized corrasion can be predicted.

\section{Conclusion}

This paper has established the framesvork, issues, limilations, tools, and competencies required to asscss an aging, complex, engineering system in tcrms life prediction and assessment. It addresses the importance of :

- integrating the information derived from surveillance units will the system assessment or establishing an cnhanced surveillance manlagcment program,

- integrating fundamental infornation on material behavior to the risk assessment,

- improving measurenuent techniques on surveillance sysicms and integrating this information, such as aged-material propertics, in the deteministie computational models.

- performing refined ealeulations of the mission environments that incorporate defects. Welding or tabrication residual stress eltects, or aged-material properics, and

\section{References}

1. Morris, and Vora, Nuclear Plant Aging Research (NPAR) Proganm Plan, NUREG-1 144 (Rev. 1). Divisian ar Engineering Tectralogy, Otree of the Nuelear Regulatory Rescareh. U.S. Nuclear Regulatory Commission, Washington, DC, July 1985

2. Edited by Sinnappan, Meligi, Nyrayanan, Bond. Power Plant Systems/Components Aging Management and Life Extension, 1991, PVP-Vul. 208, ISBN 0-7918-0802-5

3. Edited by Shah, Macronald, Aging and Life Extension of Major Light Water Reactor Components, 1993, ISBN 04444-894448-9 